\title{
Main and Trace Element Distribution in Slag-Leachate-Tufa System Precipitate
}

\author{
Beata Smieja-Król ${ }^{1 *}$, Arkadiusz Bauerek ${ }^{2}$, Małgorzata Bebek ${ }^{2}$ \\ 'Faculty of Earth Sciences, University of Silesia, \\ Będzińska 60, 41-200 Sosnowiec, Poland \\ ${ }^{2}$ Department of Environmental Monitoring, Central Mining Institute, \\ Plac Gwarków 1, 40-166 Katowice, Poland
}

Received: 18 May 2016

Accepted: 22 June 2016

\begin{abstract}
Detailed chemical and mineralogical analyses were conducted to characterize slag wastes, leachate, and associated tufa precipitates at an iron slag dump near Kraków in southern Poland. The slag contained elevated content of $\mathrm{Cr}(1,800-6,500 \mathrm{mg} / \mathrm{kg}$ ), V (500-1,800 mg/kg), and $\mathrm{Zn}$ (up to 4,500 mg/kg). The negative environmental impact posed by the wastes can be potentially caused by the formation of leachate with extremely high pH (12.5-12.9), high sulphate (720 mg/l) and K concentrations (420-520 mg/l), and elevated concentrations of fluoride (1.7-2.1 mg/l) and $\mathrm{Al}$ (up to $2.7 \mathrm{mg} / \mathrm{l}$ ). A dominant feature of the leachate was massive precipitation of calcareous tufa forming a cascade of tufa barrier ponds at the base of the slag dump. The tufa preferentially concentrated $\mathrm{Pb}, \mathrm{Sr}, \mathrm{Ba}, \mathrm{Rb}$, sulfur, and phosphorus, while $\mathrm{Fe}, \mathrm{Zn}, \mathrm{Mg}, \mathrm{Mn}, \mathrm{Cr}$, and $\mathrm{V}$ were depleted relative to the content in the slag material.
\end{abstract}

Keywords: iron slag, alkaline leachate, tufa precipitation, trace elements

\section{Introduction}

Metallurgical slags are produced in huge amounts globally as a by-product of iron and steel production. In 2014, the annual world iron slag output was estimated at 310 to 370 million tons, and steel slag at about 170 to 250 million tons based on typical ratios of slag to crude iron and steel production [1]. In Poland, the output of metallurgical slag was estimated at 2.6 million tonnes in 2014 [2]. Almost all the produced slag is being recovered and the amount of wastes accumulated during previous years is constantly decreasing [2]. Due to its very high stability and superior skid and wear resistance, the slag mate- rial is widely used for construction (i.e., support media for highway and railroad construction, stream bank protection, and railroad-grade ballast) and as such is being disseminated in areas otherwise unaffected by heavy industry, often in contact with surface water. The chemical and mineralogical composition of the slag varies depending on the furnace type and the composition of the iron ore and fluxing agents used in the process [3-5].

Highly alkaline waters $(\mathrm{pH}>11)$ are commonly formed during weathering of iron and steel slags [6]. Due to reaction of the slag material with slightly acidic to neutral rain or runoff waters, lime is hydrolysed to produce hydroxyl ions, which increase the leachate $\mathrm{pH}$ :

$$
\mathrm{CaO}_{\text {(lime) }}+\mathrm{H}_{2} \mathrm{O}_{(\mathrm{l})} \rightarrow \mathrm{Ca}^{2+}{ }_{(\mathrm{aq})}+2\left(\mathrm{OH}^{-}\right)_{(\mathrm{aq})}
$$

*e-mail: beata.smieja-krol@us.edu.pl 
Alkaline waters are commonly observed to emerge from slag dumps [e.g., 7-9] and also from construction and transportation structures (e.g., road beds, fill material), where the slag material was used [10]. In addition to extremely high $\mathrm{pH}$ values, the waters are characterized by high content of total dissolved solids (TDS), oxygen depletion, tufa precipitation, the occurrence of color and odor nuisances, and the release of sulfur. Slag-related mineral precipitation may hold rainwater, disrupt natural groundwater flow patterns, and cause bed-sediment armoring in adjacent surface-water systems [11-12]. Variations in metal concentrations of more than one order of magnitude were found in leachates from different sites [7-8]. The elements most likely to be of environmental concern in ferrous slag include As, Cr, Mn, and - rarely - Co [13].

The objective of this study was to describe the physical and chemical characteristics of a leachate in relation to the source slag material and tufa precipitates. The leachate emerges uncontrolled at a base of a large slag dump forming a cascade of tufa barrier ponds due to massive calcite precipitation. As the leaching occurs undisturbed for a prolonged period of time, the obtained data attest to the distribution and relocation of major and minor elements between slag wastes, leachate, and the precipitating tufa showing the slag's long-term environmental behaviour, which is not always predictable when using short-term leaching tests.

\section{Site Description}

Slag has been deposited since the 1950s at Central Dumping Site Pleszów near Kraków in southern Poland (Fig. 1; N: 5003'46.89”, E:2007'12.91”), which currently covers an area of about $156 \mathrm{ha}$. The deposited material is a byproduct of both blast furnace (BF) and basic-oxygen furnace (BOF) processes. Slag from an open hearth furnace was also dumped at the site into the 1990s. In addition, the dump contains furnace brick, fly-ash, and slag wastes from coal combustion. More than 20 million tons of metallurgical slag and about 15 million tons of other production wastes have been deposited at the site [14]. Nowadays the material of the dump is regularly managed as construction material.

The leachate emerges at the base the old southeastern part of the dump that is vegetated by a loose stand of bushes and trees. It forms a shallow irregular pond of milky, greenish-yellow water. Due to massive precipitation of tufa, a cascade of ponds bordered by tufa dams has formed on the western site of the main pond before reaching an outflow ditch. The northeastern part of the pond is densely overgrown with common reed (Phragmites australis). The system of ponds covers an area of $8,300 \mathrm{~m}^{2}$.

\section{Materials and Methods}

In spring 2010, three samples of slag material (W1, $\mathrm{W} 2$, and W3) were collected from the dump within approximately 20 to $80 \mathrm{~m}$ of the leachate pond (Fig. 1). Sample W1 was collected from the dump slope directly above the pond. The sample represents loose material exposed to rain and runoff water. Samples W2 and W3 were collected at the top of the dump under the influence of infiltrating rainwater. Sample W2 was collected 0.1-0.3 m below the waste surface and consists of poorlycompacted wastes. Sample W3, collected 1.7-1.9 m below waste surface, is comprised of more compact material. All the samples were composed of five sub-samples collected from an area of $1 \mathrm{~m}^{2}$ to ensure the representativeness of the studied material.

Samples of tufa deposit were collected at a site west of the main pond (P1) and at the entrance to a smaller pond located to the west (P2), within a stream flowing through the cascade system (Fig. 1).

Mineral phases were identified by $\mathrm{x}$-ray powder diffraction (XRD) using the PHILIPS PW 3710 diffractometer (CoK $\alpha$ radiation) at the following settings: voltage $45 \mathrm{kV}$, current $30 \mathrm{~mA}$, impulse counting times 3 and $8 \mathrm{~s}$, and step size $0.01^{\circ} 2 \theta$. The phase identification was carried out using X'Pert plus software and ICSD database (version 2007/12). Relative mineral abundances were determined semi-quantitatively using ratios of the peak intensities of minerals. The investigations were performed at the Faculty of Earth Sciences, University of Silesia in Sosnowiec.

Chemical composition of solid samples was determined by wavelength dispersive $\mathrm{x}$-ray fluorescence spectrometry using the PW 1404 Philips spectrometer. The uncertainty of main components was $\pm 10 \%$. The trace elements of the solid samples were determined (with $\pm 10 \%$ uncertainty) by plasma emission spectrometry (ICP-OES) using a Perkin-Elmer instrument OptimaTM 5300DV after mineralization in aqua regia.

Leachate was sampled in the main upper pond (sample D1), close to the base of the dump slope (Fig. 1). Sample D2 represents water from the lower pond, located several meters from the dump base. The groundwater sample (GW5) comes from a monitoring well located $15 \mathrm{~m}$ from the upper pond and represents the first shallow aquifer with water table at $2.7 \mathrm{~m}$ below ground level.

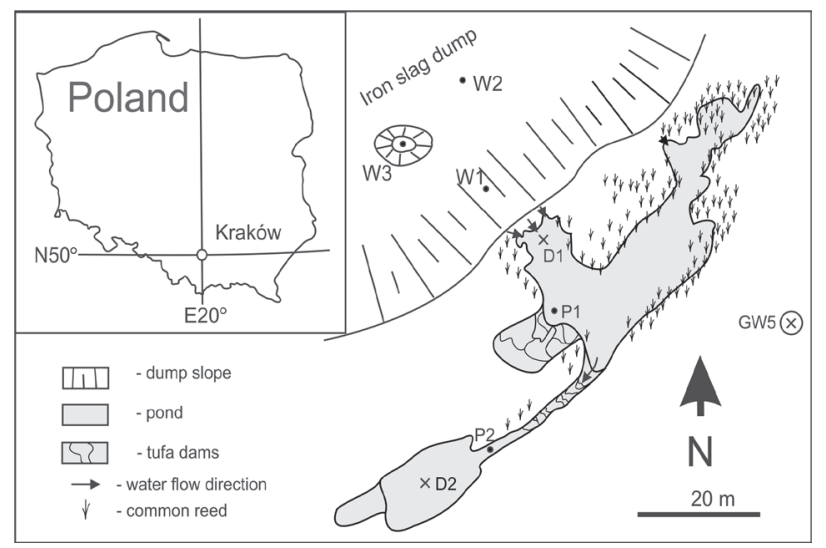

Fig. 1. Location and schematic map of the study site. 
Table 1. Composition of the slag waste.

\begin{tabular}{|c|c|c|c|}
\hline & W1 & W2 & W3 \\
\hline \multicolumn{4}{|c|}{ Major components (wt \%) } \\
\hline $\mathrm{SiO}_{2}$ & 30.64 & 20.51 & 36.36 \\
\hline $\mathrm{TiO}_{2}$ & 0.37 & 0.26 & 0.30 \\
\hline $\mathrm{Al}_{2} \mathrm{O}_{3}$ & 2.48 & 6.12 & 3.24 \\
\hline $\mathrm{Fe}_{2} \mathrm{O}_{3}$ & 26.64 & 21.26 & 19.49 \\
\hline $\mathrm{MnO}$ & 5.79 & 1.92 & 1.95 \\
\hline $\mathrm{MgO}$ & 3.91 & 13.55 & 10.86 \\
\hline $\mathrm{CaO}$ & 23.90 & 22.91 & 17.84 \\
\hline $\mathrm{Na}_{2} \mathrm{O}$ & 0.09 & 0.02 & 0.06 \\
\hline $\mathrm{K}_{2} \mathrm{O}$ & 0.13 & 0.16 & 0.15 \\
\hline $\mathrm{P}_{2} \mathrm{O}_{5}$ & 0.85 & 0.38 & 0.25 \\
\hline $\mathrm{SO}_{3}$ & 0.65 & 0.32 & 0.21 \\
\hline LOI & 3.63 & 10.47 & 7.68 \\
\hline \multicolumn{4}{|c|}{ Trace elements (mg/kg) } \\
\hline $\mathrm{Ag}$ & $<2$ & $<2$ & $<2$ \\
\hline As & $<2$ & 6 & 3 \\
\hline $\mathrm{Ba}$ & 109 & 149 & 59 \\
\hline $\mathrm{Cd}$ & $<2$ & 4 & 2 \\
\hline Co & 28 & 5 & 5 \\
\hline $\mathrm{Cr}$ & 1,824 & 6,568 & 6,295 \\
\hline $\mathrm{Cu}$ & $<2$ & 93 & 97 \\
\hline Mo & $<2$ & 6 & 4 \\
\hline $\mathrm{Ni}$ & $<2$ & 49 & 37 \\
\hline $\mathrm{Pb}$ & 36 & 82 & 43 \\
\hline $\mathrm{Rb}$ & 8 & 20 & 20 \\
\hline $\mathrm{Sb}$ & $<2$ & 10 & 10 \\
\hline $\mathrm{Sn}$ & $<2$ & 4 & 6 \\
\hline $\mathrm{Sr}$ & 110 & 142 & 97 \\
\hline $\mathrm{V}$ & 1,789 & 506 & 634 \\
\hline $\mathrm{Zn}$ & 166 & 4,498 & 557 \\
\hline
\end{tabular}

LOI - lost on ignition

GW5 was sampled using a Gigant-Whale (Eijkelkamp) electric pump.

Measurements of $\mathrm{pH}$ and electrical conductivity (EC) of unfiltered surface and ground waters were performed in the field with a WTW MultiLine P4 integrated meter. Then the water samples were filtered through a $0.45 \mu \mathrm{m}$ filter and collected into polyethylene bottles. The concentration of all metals was determined (with $10 \%$ uncertainty) by plasma emission spectrometry (ICP-OES) according to EN ISO 11885 using an Optima 5300 DV by Perkin
Elmer (USA). The titrimetric method was employed for alkalinity determination (with $10 \%$ uncertainty). The measurements were performed using a Titrando 809 automatic titration system (Metrohm, Switzerland) according to ISO 9963-1. The inorganic anions $\mathrm{SO}_{4}^{2-}$ (with $10 \%$ uncertainty), $\mathrm{Cl}^{-}$(with $8 \%$ uncertainty), $\mathrm{NO}_{3}^{-}$(with $10 \%$ uncertainty), and $\mathrm{F}^{-}$(with $10 \%$ uncertainty) were analyzed according to ISO 10304-1 using a Dionex ICS2500 ion chromatography system (USA). We applied an IonPac AS19 separator column with KOH eluent and conductivity detector for separation. Silica was determined (with 10\% uncertainty) using ICP-AES (as total $\mathrm{Si}$ ). All chemical analyses were conducted in an accredited (according to ISO/IEC 17025:2005) Laboratory of Solid Wastes Analysis and Laboratory of Water and Wastewater Analysis (Central Mining Institute, Katowice, Poland).

\section{Results and Discussion}

\section{Chemical Composition and Mineralogy of the Slag}

Slag composition is shown in Table 1. The main components are silica, together with $\mathrm{Al}, \mathrm{Fe}, \mathrm{Ca}, \mathrm{Mg}$, and $\mathrm{Mn}$ oxides, constituting $86-93 \%$ of the slag. The difference in the amount of the individual oxides between the samples results from both the weathering processes and different types of wastes deposited. Still, the content of the oxides (Table 1) is well within typical values for the BF and BOF slags [13]. Among the trace elements analyzed, $\mathrm{Cr}$ is most abundant between 1,824 and 6,568 $\mathrm{mg} / \mathrm{kg}$, exceeding the average contents in the representative number of slags [3, 13]. Vanadium, Ni, and Co are inhomogeneously distributed in the slag and their content is also elevated in comparison to contents obtained in other studies [3]. The highest $\mathrm{Zn}$ content $(4,498 \mathrm{mg} / \mathrm{kg})$ obtained for the subsurface material at the top of the dump (W2, Table 1) probably represents Zn-rich blast furnace dust [15] deposited together with the slag. The content is more than one magnitude higher than the maximum value $(150 \mathrm{mg} / \mathrm{kg})$ in BOF slag [3]. The highest $\mathrm{Zn}$ content correlates with increased $\mathrm{Pb}$ and $\mathrm{Cd}$ content in the same sample (Table 1). The other trace metals are present at relatively low contents; of these, the contents of $\mathrm{Ag}, \mathrm{As}, \mathrm{Ba}, \mathrm{Co}, \mathrm{Ni}, \mathrm{Rb}$, and $\mathrm{Sr}$ are below or close to the average composition of continental crust [16].

Major phases determined by XRD in sample W1 are included in decreasing order of abundance: quartz, kirschsteinite $\left(\mathrm{CaFe}^{2+} \mathrm{SiO}_{4}\right)$, magnetite $\left(\mathrm{Fe}^{2+} \mathrm{Fe}^{3+}{ }_{2} \mathrm{O}_{4}\right)$ and/or magnesioferrite $\left(\mathrm{MgFe}^{3+}{ }_{2} \mathrm{O}_{4}\right)$, calcite, wüstite $(\mathrm{FeO})$ and $\alpha \mathrm{Fe}, \mathrm{Fe}$ magnesite $\left((\mathrm{Mg}, \mathrm{Fe}) \mathrm{CO}_{3}\right), \mathrm{CaO}$, feldspars, dolomite, phase from the melilite group (akermanite-gehlenite, $\left.\quad \mathrm{Ca}_{2}(\mathrm{Mg}, \mathrm{Al})(\mathrm{Si}, \mathrm{Al})_{2} \mathrm{O}_{7}\right)$, and traces of srebrodolskite $\left(\mathrm{Ca}_{2} \mathrm{Fe}^{3+}{ }_{2} \mathrm{O}_{5}\right)$. The presence of both the unhydrated lime $(\mathrm{CaO})$ and calcite indicates an ongoing weathering process taking place on the dump slope [17]. 


\section{Physical and Chemical Characteristics of Leachate}

The leachates are characterized by extremely high $\mathrm{pH}$ values (12.8-12.9) and electrical conductivity as high as $5.2-8.4 \mathrm{mS} / \mathrm{cm}$ (Table 2). The nearby well (GW5) showed values of $12.5 \mathrm{pH}$ and $4.5 \mathrm{mS} / \mathrm{cm}$, respectively. $\mathrm{Ca}$ concentration decreases from $270 \mathrm{mg} / \mathrm{l}$ in the main pond (D1) to a value of $12.7 \mathrm{mg} / 1$ in the lower pond (Table 2), due to massive tufa precipitation occurring predominantly in the main pond. The $\mathrm{Ca}$ concentration in the well water is $6.3 \mathrm{mg} / \mathrm{l}$ as a consequence of calcite precipitation and/or mixing with groundwater. $\mathrm{Na}, \mathrm{K}$, and chloride decreased only slightly when reaching the lower pond and the well, while the concentration of sulphate is consistently high, between $718-725 \mathrm{mg} / \mathrm{l}$. Conversely, the silicate concentration is increasing from $2.37 \mathrm{mg} / \mathrm{l}$ in the main pond to 10.6 in the lower pond, reaching the highest value of $135 \mathrm{mg} / \mathrm{l}$ in the well. Aluminium follows the same trend, reaching the highest value of $2.7 \mathrm{mg} / \mathrm{l}$ in the well. The concentration of $\mathrm{Mg}$ is low in all samples (Table 2).

The trace element concentrations are generally low, with 10 elements near or under detection limit (Table 2). $\mathrm{Sr}$ and $\mathrm{Ba}$ are visibly depleted in the lower pond and in the well relative to the main pond. The concentrations of $\mathrm{Zn}$, $\mathrm{Fe}, \mathrm{As}$, and $\mathrm{V}$ are slightly higher in groundwater than in the surface water. The fluoride concentration is between $1.73-2.12 \mathrm{mg} / \mathrm{l}$, with the highest value determined in the main pond (Table 2).

\section{Mineralogy and Chemical Composition of Tufa Precipitates}

The tufa deposit is composed of almost pure calcite as revealed by the XRD analysis. Sample P1 contains in addition small amounts of quartz $(\sim 3 \mathrm{vol} \%)$ and sample P2quartz ( $\sim 10-12 \mathrm{vol} \%)$, feldspar ( $\sim \mathrm{vol} \%), \alpha \mathrm{Fe}(\sim 2 \mathrm{vol} \%)$, and traces of hematite $(\sim 1 \mathrm{vol} \%)$. They were probably transported into the calcite tufa as suspension along with the leachate and/or deposited as dust particles from the slag heaps. Chemical analyses indicates a low $\mathrm{Mg}$ content of the precipitate and high $\mathrm{SO}_{3}$ content comparable to the slag material. Detailed chemical composition of the tufa precipitate is presented in Table 3.

A distribution index was calculated to quantify the amount of individual metals gained by the tufa relative to the source material composition:

$$
\left.\mathrm{DI}_{\mathrm{M}}=([\mathrm{M}] /[\mathrm{Ti}])_{\text {tufa }} /([\mathrm{M}] / \mathrm{Ti}]\right)_{\text {slag }}
$$

... where $\mathrm{M}$ is the metal of interest.

The distribution index shows the preference of the metal to be immobilized in the tufa deposit compared to the content of that metal in the slag. The element of interest was normalized to Ti content. Ti is a conservative element, immobile at high $\mathrm{pH}$ [7]. In the tufa deposits, most Ti was probably transported in the suspension. A small addition of Ti gained by co-precipitation with calcite cannot be
Table 2. Physico-chemical characteristics of leachate.

\begin{tabular}{|c|c|c|c|}
\hline & $\begin{array}{c}\mathrm{D} 1 \\
\text { (main pond) }\end{array}$ & $\begin{array}{c}\mathrm{D} 2 \\
\text { (lower pond) }\end{array}$ & $\begin{array}{c}\text { D5 } \\
\text { (well) }\end{array}$ \\
\hline $\mathrm{pH}$ & 12.8 & 12.9 & 12.5 \\
\hline $\mathrm{EC}(\mu \mathrm{S} / \mathrm{cm})$ & 8,430 & 5,160 & 4,520 \\
\hline \multicolumn{4}{|c|}{ Major ions (mg/l) } \\
\hline $\mathrm{Ca}$ & 271 & 13 & 6.3 \\
\hline $\mathrm{Mg}$ & 0.072 & 0.134 & $<0.005$ \\
\hline $\mathrm{Na}$ & 667 & 598 & 559 \\
\hline $\mathrm{K}$ & 520 & 477 & 422 \\
\hline $\mathrm{Cl}$ & 406 & 372 & 283 \\
\hline $\mathrm{SO}_{4}$ & 725 & 724 & 718 \\
\hline $\mathrm{CO}_{3}$ & 45 & 207 & 174 \\
\hline $\mathrm{OH}$ & 467 & 124 & 111 \\
\hline $\mathrm{NO}_{3}$ & 1.49 & 6.89 & $<0.5$ \\
\hline $\mathrm{SiO}_{3}$ & 2.37 & 10.6 & 135 \\
\hline $\mathrm{F}$ & 2.12 & 2.11 & 1.73 \\
\hline \multicolumn{4}{|c|}{ Minor ions $(\mu \mathrm{g} / \mathrm{l})$} \\
\hline $\mathrm{Al}$ & $<50$ & 580 & 2,700 \\
\hline As & $<10$ & $<10$ & 55 \\
\hline $\mathrm{B}$ & 200 & 230 & 240 \\
\hline $\mathrm{Ba}$ & 85 & $<30$ & $<30$ \\
\hline $\mathrm{Cd}$ & $<1$ & $<1$ & $<2$ \\
\hline Co & $<5$ & $<5$ & $<5$ \\
\hline $\mathrm{Cu}$ & $<10$ & 11 & 14 \\
\hline $\mathrm{Cr}$ & 4 & 7 & $<5$ \\
\hline $\mathrm{Fe}$ & 120 & 32 & 500 \\
\hline $\mathrm{Hg}$ & $<1$ & $<1$ & $<1$ \\
\hline $\mathrm{Mn}$ & $<5$ & $<5$ & 7 \\
\hline Mo & 40 & 40 & 23 \\
\hline $\mathrm{Ni}$ & 17 & 15 & 25 \\
\hline $\mathrm{Pb}$ & $<10$ & $<10$ & $<20$ \\
\hline $\mathrm{Sr}$ & 1,000 & 270 & 30 \\
\hline $\mathrm{Ti}$ & $<5$ & $<5$ & 7 \\
\hline V & 42 & 42 & 140 \\
\hline $\mathrm{Zn}$ & 70 & 69 & 110 \\
\hline
\end{tabular}

excluded as Ti was detected in one water sample (GW5) in a dissolved form.

In spite of some differences in the mineralogical composition between the two analyzed samples (resulting probably from a contamination of sample $\mathrm{P} 2$ by the slag material - either by suspension and/or by dust deposition), the element abundances in the tufa precipitate relative 
Table 3. Composition of the tufa precipitate.

\begin{tabular}{|c|c|c|}
\hline & P1 & $\mathrm{P} 2$ \\
\hline \multicolumn{3}{|c|}{ Major components (wt \%) } \\
\hline $\mathrm{SiO}_{2}$ & 2.84 & 10.87 \\
\hline $\mathrm{TiO}_{2}$ & 0.02 & 0.05 \\
\hline $\mathrm{Al}_{2} \mathrm{O}_{3}$ & 0.09 & 0.98 \\
\hline $\mathrm{Fe}_{2} \mathrm{O}_{3}$ & 0.91 & 3.02 \\
\hline $\mathrm{MgO}$ & 0.25 & 0.65 \\
\hline $\mathrm{CaO}$ & 52.49 & 46.73 \\
\hline $\mathrm{Na}_{2} \mathrm{O}$ & 0.06 & 0.12 \\
\hline $\mathrm{K}_{2} \mathrm{O}$ & 0.09 & 0.25 \\
\hline $\mathrm{P}_{2} \mathrm{O}_{5}$ & 0.12 & 0.18 \\
\hline $\mathrm{SO}_{3}$ & 0.47 & 0.60 \\
\hline LOI & 42.22 & 35.84 \\
\hline \multicolumn{3}{|c|}{ Trace elements (mg/kg) } \\
\hline $\mathrm{Ag}$ & $<2$ & $<2$ \\
\hline As & $<2$ & $<2$ \\
\hline $\mathrm{Ba}$ & 53 & 117 \\
\hline $\mathrm{Cd}$ & $<2$ & $<2$ \\
\hline Co & $<3$ & $<3$ \\
\hline $\mathrm{Cr}$ & 20 & 143 \\
\hline $\mathrm{Cu}$ & $<2$ & $<2$ \\
\hline $\mathrm{Mn}$ & 415 & 1,796 \\
\hline Mo & $<2$ & $<2$ \\
\hline $\mathrm{Ni}$ & $<2$ & $<2$ \\
\hline $\mathrm{Pb}$ & 14 & 20 \\
\hline $\mathrm{Rb}$ & 6 & 15 \\
\hline $\mathrm{Sb}$ & $<2$ & $<2$ \\
\hline $\mathrm{Sn}$ & $<2$ & $<2$ \\
\hline $\mathrm{Sr}$ & 540 & 753 \\
\hline V & 26 & 68 \\
\hline $\mathrm{Zn}$ & 33 & 52 \\
\hline
\end{tabular}

LOI - lost on ignition

to slag material show a consistent pattern (Fig. 2). The precipitate incorporates $\mathrm{Sr}, \mathrm{S}, \mathrm{Ba}, \mathrm{Rb}, \mathrm{Pb}$, and phosphorous most effectively, while $\mathrm{Fe}, \mathrm{Zn}, \mathrm{Mg}, \mathrm{Mn}, \mathrm{Cr}$, and $\mathrm{V}$ are depleted relative to the content in the slag material (Fig. 2). This agrees with the lower concentration of $\mathrm{Sr}$ and $\mathrm{Ba}$ in the lower pond (D2, Table 2). $\mathrm{Cu}, \mathrm{Mo}, \mathrm{Co}$, and $\mathrm{Ni}$ are not incorporated in the tufa in measurable amounts despite their occurrence in the slag at levels comparable to $\mathrm{Pb}$ (Table 1). While $\mathrm{Pb}$ is below detection limit in the leachate, $\mathrm{Mo}, \mathrm{Ni}$, and $\mathrm{Cu}$ were found in a dissolved form in the pond

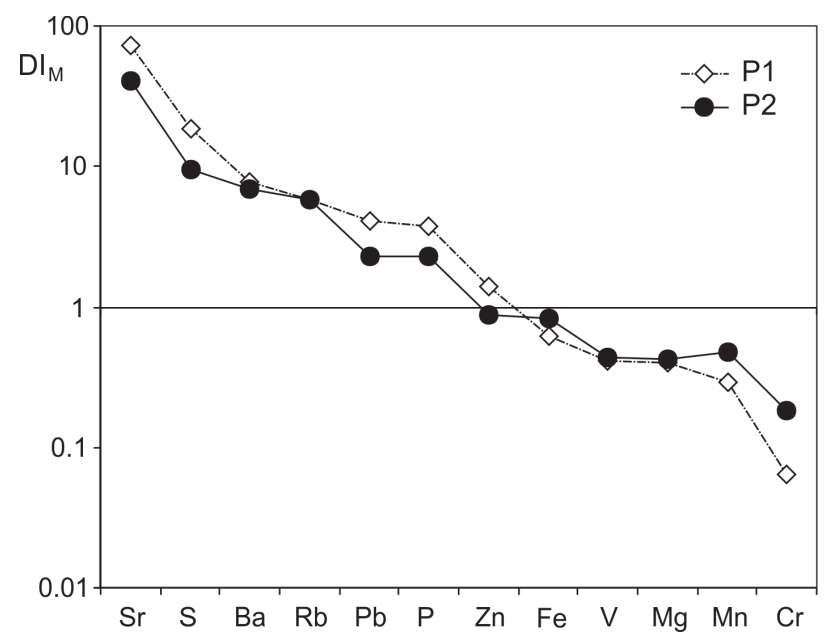

Fig. 2. Enrichment/depletion of trace elements in tufa in relation to slag material.

water (Table 2). The higher values of the index obtained for $\mathrm{Sr}, \mathrm{S}, \mathrm{Ba}, \mathrm{Pb}, \mathrm{P}$, and $\mathrm{Zn}$ in sample $\mathrm{P} 1$ in comparison to sample P2 are consistent with the higher calcite content in the sample, as evident from the chemical analysis and XRD data. This suggests that the elements are associated with the calcite precipitates rather than originating from suspended matter or dust deposition.

\section{Environmental Implication of Element Distribution in the System}

The main impact of the leachates on the environment results from their extremely high $\mathrm{pH}$ and ability for rapid formation of tufa crusts. Several studies have confirmed the negative influence of limed waters on aquatic life [18-19]. The leachate and groundwater $\mathrm{pH}$ is above the regulatory threshold for discharge to water bodies. Also, the high concentrations of K (mean $473 \mathrm{mg} / \mathrm{l}$ ) and sulphate (mean $722 \mathrm{mg} / \mathrm{l}$ ) exceeded the criteria presented in the Regulation of the Minister of Environmental Protection [20] for industrial wastewater ( 80 and $500 \mathrm{mg} / \mathrm{l}$, respectively). In contrast to $\mathrm{Ca}$, the $\mathrm{pH}$ value, $\mathrm{K}$, and sulfate concentrations are not reduced during tufa precipitation.

Boron and fluoride are in concentrations that can be potentially toxic, particularly if the slag material is used at sites in contact with aquatic ecosystems. High concentrations of boron (up to $2.1 \mathrm{mg} / \mathrm{l}$ ) were also observed during leaching tests of 15-year-old slag [21]. Among the potentially toxic elements, $\mathrm{Al}$ is the only one, which showed a clear increasing trend during the leachate evolution.

Among the metals and metaloids analyzed in slag (Table 1), As, Sn, Zn, Cd, Cu, Ni, V, and Mo are potentially mobile at the extremely high $\mathrm{pH}$ by forming oxyanions $[19,22]$. For example, alkaline waters studied by [22] (generated by interaction of groundwater with aluminum production wastes) contained markedly higher As (up to $5.2 \mathrm{mg} / \mathrm{l}$ ), Mo (up to $2.6 \mathrm{mg} / \mathrm{l}$ ), and $\mathrm{V}$ (up to $5.4 \mathrm{mg} / \mathrm{l}$ ) concentrations than the investigated slag leachate, and 
showed comparably high $\mathrm{pH}$ values. In the investigated system, the release of these trace elements is restricted by their low content in the slag rather than immobility in an alkaline environment. However, the As concentration in the groundwater sample (GW5) is higher $(0.055 \mathrm{mg} / \mathrm{l})$ by an order of magnitude than the maximum values obtain during leaching tests for both $\mathrm{BF}$ and $\mathrm{BOF}$ slag $(0.005 \mathrm{mg} / \mathrm{l})$, regardless of $\mathrm{pH}$ of water used [3, 21]. Restricted mobility observed for $\mathrm{Sr}, \mathrm{Rb}, \mathrm{Ba}$, and $\mathrm{Pb}$ can be explained by their coprecipitation with calcite.

\section{Conclusions}

The slag wastes contain high and variable contents of $\mathrm{Cr}, \mathrm{V}$, and $\mathrm{Zn}$, while the contents of other trace metals are generally low. The slag material reveals a high chemical reactivity despite long-time deposition at the site. The emerging leachate is characterized by extremely alkaline $\mathrm{pH}$, high sulphate and $\mathrm{K}$ contents, and elevated concentrations of $\mathrm{F}$ and $\mathrm{Al}$. The trace metal content in the leachate stays at environmentally permissible levels. A dominant feature of the leachate is massive precipitation of calcareous tufa, which preferentially incorporates $\mathrm{Pb}, \mathrm{Sr}, \mathrm{Ba}, \mathrm{Rb}$, sulfur, and phosphorus. The elevated As concentration in groundwater, despite its low content in the slag, requires further study.

\section{References}

1. U.S. GEOLOGICAL SURVEY. Mineral commodity summaries 2015: U.S. Geological Survey, 2015.

2. CENTRAL STATISTICAL OFFICE. Environment 2014. Statistical Information and Elaboration. Warszawa. Central Statistical Office, 2014.

3. PROCTOR D.M., FEHLING K.A., SHAY E.C., WITTENBORN J.L., GREEN J.J., AVENT C., BIGHAM R.D., CONNOLLY M., LEE B., SHEPKER T.O., ZAK M.A. Physical and Chemical Characteristics of Blast Furnace, Basic Oxygen Furnace, and Electric Arc Furnace Steel Industry Slags. Environ. Sci. Technol. 34, 1576, 2000.

4. JONCZY I., LATA L. Characteristic of chemical composition of converter and blast furnace slags (in Polish with English summary). Górnictwo i Geologia 8, 51, 2013.

5. ILUȚIU-VARVARA D.-A. Researching the Hazardous Potential of Metallurgical Solid Wastes. Pol. J. Environ. Stud. 25 (1), 147, 2016.

6. RILEY A.L., MAYES W.M. Long-term evolution of highly alkaline steel slag drainage waters. Environ. Monit. Assess. 187, 463, 2015.
7. ROADCAP G.S., KELLY W.R., BETHKE C.M. Geochemistry of Extremely Alkaline ( $\mathrm{pH}>12)$ Ground Water in SlagFill Aquifers. Ground Water 43, 806, 2005.

8. MAYES W.M., YOUNGER P.L., Aumônier J. Hydrogeochemistry of Alkaline Steel Slag Leachates in the UK. Water Air Soil Pollut 195, 35, 2008.

9. VANTREES C. Analysis of Precipitates and Waters Associated with an Alkaline Leachate, Gulf State Steel Property, Gadsden, Alabama: A Reconnaissance Study. Thesis, Georgia State University, 2010.

10. BOYER B.W. Alkaline leachate and calcareous tufa originating from slag in a highway embankment near Baltimore, Maryland. Transport Res Rec 1434, 3, 1994.

11. BAYLESS E.R., SCHULZ M.S. Mineral precipitation and dissolution at two slag-disposal sites in northwestern Indiana, USA. Environ. Geol. 45, 252, 2003.

12. MEIMA J.A., REGENSPURG S., KASSAHUN A., RAMMLMAIR D. Geochemical modelling of hardpan formation in an iron slag dump. Miner. Eng. 20, 16, 2007.

13. PIATAK N.M., PARSONS M.B., SEAL II R.R. Characteristics and environmental aspects of slag: A review. Applied Geochem. 57, 236, 2015.

14. DZIARMAGOWSKI M. Possibilities of converter slag utilization. Archives of Metallurgy and Materials 50 (3),769, 2005.

15. JEZIERSKI J., JANERKA K. Selected aspects of metallurgical and foundry furnace dust utilization. Pol. J. Environ. Stud. 20 (1), 101, 2011.

16. RUDNICK R.L., GAO S. Composition of the continental crust. In H. D. Holland, K. K. Turekian (Eds), Treatise on Geochemistry 3. Elsevier, 2003.

17. JONCZY I. Forms of calcium occurrence in slags after steel production. Archives of Waste Management and Environmental Protection 16, 77, 2014.

18. HULL S.L., OTY U.V., MAYES W.M. Rapid recovery of benthic invertebrates downstream of hyperalkaline steel slag discharges. Hydrobiologia 736, 83, 2014.

19. GOMES H.I., MAYES W.M., ROGERSON M., DOUGLAS I. STEWART D.I., BURKE I.T. Alkaline residues and the environment: a review of impacts, management practices and opportunities. Journal of Cleaner Production 112, 3571, 2016.

20. REGULATION OF THE MINISTER OF ENVIRONMENTAL PROTECTION OF DEC. 16, 2015 (Dz. U. poz. 1800), 2015.

21. SOETYSIAK M. The dynamic tests of leaching from metallurgical slags of the Katowice steelwork (in Polish with English summary). Biuletyn Państwowego Instytutu Geologicznego 436, 475, 2009

22. CZOP M., MOTYKA J., SRACEK O., SZUWARZYŃSKI M. Geochemistry of the Hyperalkaline Gorka Pit Lake $(\mathrm{pH}>13)$ in the Chrzanow Region, Southern Poland. Water Air Soil Pollut 214, 423, 2011. 